\begin{tabular}{l}
\hline sciendo $\frac{\text { ECONOMIC THEMES (2020) 58(2): 235-253 }}{\text { DOI } 10.2478 / \text { ethemes-2020-0014 }}$ \\
\hline
\end{tabular}

\title{
COST ACCOUNTING AND PERFORMANCE MEASUREMENT WITH THE PURPOSE OF INCREASING THE COMPETITIVENESS OF SPORTS ORGANIZATIONS
}

\author{
Bojana Novićević Čečević \\ University of Niš, Faculty of Economics, Republic of Serbia \\ $\triangle$ bojana.novicevic@eknfak.ni.ac.rs \\ Ljilja Antić \\ University of Niš, Faculty of Economics, Republic of Serbia \\ \jilja.antic@eknfak.ni.ac.rs \\ Kristina Spasić \\ PhD student at University of Niš, Faculty of Economics, Republic of Serbia \\ $\bowtie k .88 . s p a s i c @ g m a i l . c o m$ \\ UDC \\ 336.71 \\ (497.6) \\ Review \\ paper

\begin{abstract}
Dynamic business environment, rise in the share of overheads in total costs, strong competition on the global market and numerous other challenges that organizations are facing have imposed the need to reexamine the existing, design new costing methods and apply more appropriate management tools to improve management information basis, maintain and improve competitive advantage. In addition to traditional costing methods, organizations apply the methods adapted to the changing business environment, such as Activity-Based Costing (ABC). The positive experiences of manufacturing organizations which apply activity-based costing have led to the expansion of $\mathrm{ABC}$ application among service organizations. Changes in cost accounting are in line with changes in performance measurement systems, all for the purpose of improving the functioning of organizations and successfully responding to the demands of a changing business environment. The paper analyzes the possibility of applying activity-based costing and Balanced Scorecard in sports organizations that provide a large number of specific services.
\end{abstract}

Received: 21.02.2020 Accepted: 14.05.2020
Keywords: costing, activities, costs, sports organizations, Balanced Scorecard

JEL classification: M41 


\section{Introduction}

Sports organizations, as well as manufacturing ones, must carefully record and account for costs, since information about them is a significant basis for performing various management activities, especially for making important business decisions. It is also very important to manage costs wisely, as costs are one of the key factors for success and maintaining and improving competitiveness. The accuracy and reliability of cost information depends on the costing method used. Traditional costing systems, relying on narrower organizational units and using cost allocation related to the physical volume of production as conceptual bases, cannot fully meet the requirements for providing reliable cost information in organizations with a prevailing share of overhead in total costs, which is especially distinctive for the service sector. Sports organizations, which provide a large number of different services to clients, face the problem of choosing the right costing method, which will be a reliable basis for business decision-making and preserving and enhancing competitive advantage. In addition to traditional costing methods, sports organizations apply activity-based costing to more accurately determine the total cost of a product/service, as well as the real cost of the product/service, to identify value-added and non-value-added activities to better manage them.

The costing method, adapted to the changed business environment and the needs of the organization, should be combined with an adequate performance measurement system, all with the aim of providing a reliable information base for business decision-making, implementing a defined strategy and improving the competitiveness of service organizations. One of the management tools that support the process of strategic planning and management through monitoring and keeping records of employees' activities, while respecting the financial and nonfinancial aspects of the organization, is Balanced Scorecard (BSC), which is widely applied in service organizations. The application of BSC will be illustrated using the example of a sports organization.

The paper structure consists of three parts. The first part outlines the specific features and types of sports organizations. The second part illustrates the application of activity-based costing in a hypothetical sports organization. The third part of the paper outlines the Balanced Scorecard perspectives and the possibility of its application in sports organizations.

\section{The term and types of sports organizations}

A sports organization is a social entity in the sports industry with a goal-oriented and consciously structured system of activities. (Slack 1997, p. 5). The current 2016 Sports Law of the Republic of Serbia distinguishes between a sports organization and an organization in the field of sports. "A sports organization is an 
organization set up for the pursuit of sports activities and sports business", while an organization in the field of sports is "any legal entity and entrepreneur engaged in the organization of sports activities and performing sports business in accordance with the law" (www.mos.gov.rs). Depending on the source of funding, sports organizations may be: for-profit, non-profit, donor, donor-commercial, and commercial-donor organizations (Ćosić 2012, p. 135). When it comes to sports organizations such as clubs, for-profit clubs are professional and non-profit clubs are amateur sports clubs (Milić 2009, p. 16). If professional sports clubs' goal was to win, then relatively few of them would achieve that goal. For this reason, the football league founders have defined their primary purpose of existence as providing some form of sports entertainment, while local amateur sports clubs aim to enable individuals to engage in sports and other forms of recreation (Beech, Chadwick 2004, p. 72). Most sports organizations focus on sports promotion and development, so this criterion allows distinguishing between the following types of sports organizations (Gómez et al. 2007, p. 4):

- Sport governing bodies,

- Sport event organizations and

- Sport providing entities.

Sport governing bodies include: national associations, sports federations, national organizations and the like. These bodies guarantee the rules of the game and competition in the field of sports, they also manage, regulate, promote and monitor sports development at all levels and in a given sports discipline. Their goal is to manage sports in terms of sports promotion and development at all levels, to monitor sports administration, to ensure that competitions are held regularly and to respect the rules of the game.

Sport event organizations aim to create a regular competition system that will allow competition between rival teams, or individually, in a given sports discipline in accordance with a predefined code of ethics. Sports leagues, sports associations etc. are an example of these organizations. Sport event organizations promote and protect the interests of all participants in the competition and produce a competitive system in order to meet the needs of the sport.

Sport providing entities imply organizations that produce and provide recreational or competitive sports programs at the local or community level. Their mission is to motivate the community to engage in physical activity and to facilitate socializing through sporting activities. The aim of these organizations is to design and offer sports activities at the recreational and competitive levels in the form of individual and team programs oriented towards formal competitions to ensure social integration and sporting success. This includes sports clubs, social and fitness centers etc.

Within sports clubs, one can distinguish between professional sports clubs and teams, amateur sports clubs and national teams (Manev, Jakimovski 2017, p. 152). 
Professional sports clubs and teams compete in their regional leagues, national championships and European team championships. This also includes national teams whose members have certain incomes and bonuses. Unlike professional sports clubs and teams, the amateur sports clubs' driving force is enthusiasm and they reveal future top athletes. National teams participate in European and World Cup matches.

Compared to manufacturing companies, sports organizations are distinguished by the following specific characteristics (Beech, Chadwick 2004, p. 16):

- The meaning of the existence of every sports organization is conditioned by the direct competitors with whom it must cooperate and coordinate its work in order to maintain that competition;

- The governing bodies of sports organizations control the organization of competition and act as a cartel;

- The focus of a sports organization is on the organization of sporting events that sometimes take place on its own premises and sometimes on the premises of direct competitors, or, rarely, on neutral ground;

- A set of competitors is defined as a "league" and changes every year as a result of sports performance over the year, with these changes affecting revenue, but not cost;

- Direct revenues from competitions such as the "sports league" are usually seasonal in nature;

- Since sports competitions are seasonal, sports organizations seek to find more regular sources of income through activities such as the sale of sports products and the like. With increasing commercialization, direct revenues (membership fees) account for a declining percentage of sports organizations' total revenue;

- Sport is attractive to individuals because the outcome of sports competitions is uncertain and cannot be predicted.

No matter what type of sports organization it is, just like the manufacturing organization, it should run its business professionally and base its competitive advantage not on what it has, but on what it knows and is capable of doing much better than competitors.

\section{Application of activity-based costing in sports organizations}

Activity-Based Costing (ABC) is a costing method that provides financial and nonfinancial cost information, establishes a link between them and analyzes and evaluates activities in detail. Activity-based costing involves a two-level cost allocation process. It first assigns resource costs to activities performed in the organization, and then activity costs to cost objects. 
The process of cost allocation in activity-based costing involves the following (Weygandt et al 2008, p. 152):

- Identifying and classifying activities involved in the manufacturing process and allocating overhead costs to appropriate activities,

- Identifying cost drivers associated with activity costs,

- Calculating the overhead cost rate for each cost driver and

- Allocating overhead manufacturing costs from activity costs to products, using the overhead rate for each cost driver.

The original concept of activity-based costing was first implemented at Siemens AG in 1975, and in early 1980s a large number of manufacturing organizations adopted it. Having realized the many benefits of activity-based costing information, the service sector also widely accepted it.

Specifically, it is possible to identify a number of indicators that an organization should review, e.g. the use of cost information produced by existing costing methods, such as (Estrin et al 1994, p. 40): the number and variety of products it produces and the service it provides, diversity and the degree of service support accompanying individual products, the extent to which shared processes are used, the efficiency of the current cost allocation method, and the growth rate of current period revenue.

Activity-based costing has been successfully implemented in non-profit and service organizations (Antić \& Sekilić, 2016), so its implementation in sports organizations, where service activities are predominant, would provide adequate support for cost management and business decision-making. Some sports organizations have simpler activities and spend little resources, such as weekly training sessions for ten adults, while others spend more resources and time, such as a sports camp that receives over three hundred campers during the summer season, and activity-based costing respects the specifics of both (Lussier, Kimball 2014, p. 419).

The 2005 survey by Drury and Tayles in the UK indicates that service sector organizations are more interested in implementing $\mathrm{ABC}$ than manufacturing organizations. Of the total financial and service organizations surveyed, $51 \%$ implement this costing method, with only $15 \%$ of the total number of production organizations (Drury 2008, p. 236).

Effective implementation of activity-based costing in sports organizations involves the following steps (Dimitropoulos 2007, p. 22-23):

1. Identifying organizational units within the sports organization;

2. Investigating the costs of each organizational unit and identifying cost objects;

3. Recording the activities of each organizational unit;

4. Identifying the resources necessary to carry out the activity;

5. Determining cost drivers of each activity; 
6. Allocating overhead costs of each organizational unit to activities according to the predefined cost drivers;

7. Transfer of activity costs to pre-defined cost objects;

8. Calculating total costs (or per unit) of cost objects, depending on the objective of the survey.

We illustrate the implementation of activity-based costing in sports organizations using the example of "RELAX", a hypothetical fitness center (club). (Example adapted from: Boussabaine at al 1999, p. 452-461; Antić, Novićević Čečević 2016, p. 586; Kosmas, Dimitropoulos 2014, p. 130-138). Here we assume that the fitness center (club) provides services to prospective customers in the form of the following fitness programs: gym, Pilates, body shape, zumba and aerobics. Each of these fitness programs is a separate cost object.

The resources needed for a fitness center are the following: coaches, administration staff, equipment, facilities and other resources. Different types of sports organizations perform different activities. Most often, a sports organization identifies individual training activities, group training activities and administrative activities. In case the fitness center has a swimming pool, jacuzzi, sauna and the like, in addition to the classic gym, the list of activities is expanded.

Suppose, in our example, the costs of individual and group training activities amount to $6,000,000 \mathrm{RSD}$ and relate to the costs of coaches' salaries, so they are, as direct costs, allocated to cost objects, i.e. to fitness programs the club offers in the following amounts: Pilates 600,000 RSD, body shape 1,200,000 RSD, zumba 600,000 RSD, aerobics 1,200,000 RSD and gym 2,400,000 RSD. Overhead costs arise from administrative staff activities (costs of administrative staff salaries) and amount to $840,000 \mathrm{RSD}$, while the costs related to equipment, electricity, rent and other resources amount to 7,648,000 RSD.

Overhead resource costs are allocated to activities through appropriate cost drivers, while the costs of individual and group training are directly allocated to cost objects - services.

The costs of administrative staff salaries are allocated to the relevant activities based on the number of persons employed. The number of technical support persons hired is 1 , administrative staff $2^{1}$ and current maintenance staff 1 . Table 1 shows administrative staff salary cost allocation.

Cost allocation related to equipment and supplies, electricity, rent and other resources is made by applying the appropriate resource cost drivers.

${ }^{1}$ Administrative services include enrollment of new members, issuance of membership cards, introducing clients to the fitness club etc. 
Table 1. Administrative staff salary cost allocation

\begin{tabular}{||l|c|c|c||}
\hline Activities & $\begin{array}{c}\text { Number of persons } \\
\text { employed }\end{array}$ & $\%$ share & $\begin{array}{c}\text { Allocated cost } \\
\text { amount }\end{array}$ \\
\hline Technical support & 1 & $25 \%$ & 210.000 \\
\hline Administrative services & 2 & $50 \%$ & 420.000 \\
\hline Current maintenance & 1 & $25 \%$ & 210.000 \\
\hline Total & 4 & $100 \%$ & 840.000 \\
\hline
\end{tabular}

The allocation of equipment and supplies costs is based on hours of equipment use. Information on the real needs for the equipment provides data on the hours of use of the equipment. The allocation of equipment and supplies costs to the respective activities is shown in Table 2.

Table 2. Allocation of equipment and supplies costs to activities

\begin{tabular}{||l|c|c|c||}
\hline \multicolumn{1}{||}{ Activities } & $\begin{array}{c}\text { Hours of } \\
\text { equipment use }\end{array}$ & $\%$ share & $\begin{array}{c}\text { Amount of } \\
\text { allocated costs }\end{array}$ \\
\hline Individual training & 40.000 & $66,69 \%$ & 796.761 \\
\hline Group training & 14.235 & $23,73 \%$ & 283.547 \\
\hline Technical support & 1.540 & $2,57 \%$ & 30.675 \\
\hline Administrative services & 3.100 & $5,17 \%$ & 61.749 \\
\hline Current maintenance & 1.100 & $1,83 \%$ & 21.911 \\
\hline Total & 59.975 & $100 \%$ & 1.194 .644 \\
\hline
\end{tabular}

Allocation of costs of electricity, rent and other resources is made on the basis of the facility surface given in $\mathrm{m}^{2}$. The facility surface for individual training is $40 \mathrm{~m}^{2}$, for group training activities $60 \mathrm{~m}^{2}$, for technical support activities $1 \mathrm{~m}^{2}$, for administrative activities $5 \mathrm{~m}^{2}$ and for maintenance $20 \mathrm{~m}^{2}$. Table 3 shows the allocation of costs of electricity, rent and other resources to activities.

\section{Table 3 Allocation of costs of electricity, rent and other resources to activities}

\begin{tabular}{|l|c|c|c|}
\hline \hline Activities & $\begin{array}{c}\text { Surface in } \\
\mathrm{m}^{2}\end{array}$ & $\%$ share & $\begin{array}{c}\text { Amount of } \\
\text { allocated costs }\end{array}$ \\
\hline Individual training & 40 & $31,75 \%$ & 2.048 .684 \\
\hline Group training & 60 & $47,62 \%$ & 3.073 .027 \\
\hline Technical support & 1 & $0,79 \%$ & 51.217 \\
\hline Administrative services & 5 & $3,97 \%$ & 256.086 \\
\hline Current maintenance & 20 & $15,87 \%$ & 1.024 .342 \\
\hline Total & 126 & $100 \%$ & 6.453 .356 \\
\hline
\end{tabular}


In the example, we classify operating costs into two groups: equipment and supplies and electricity, rent and other resources. In some sports facilities, these costs can be divided into four groups (Langston, Lauge-Kristensen 2011, p. 146.; Boussabaine at al 1999, p. 452):

- Rent costs, capital expenditures used for procurement, taxes and salary insurance;

- Utilities, network system costs;

- Costs of tertiary services - cleaning, repair, maintenance, telecommunications etc, and

- Staff costs.

An overview of overall resource costs allocated to activities is presented in Table 4.

Table 4. Total costs of activities

\begin{tabular}{||l|c|c|c|c||}
\hline \hline \multicolumn{1}{|c|}{ Activities } & $\begin{array}{c}\text { Salary and } \\
\text { administrative } \\
\text { staff costs }\end{array}$ & $\begin{array}{c}\text { Costs of } \\
\text { equipment } \\
\text { and supplies }\end{array}$ & $\begin{array}{c}\text { Costs of } \\
\text { electricity, rent } \\
\text { and other } \\
\text { resources }\end{array}$ & Total \\
\hline Individual training & - & 796.761 & 2.048 .684 & 2.845 .446 \\
\hline Group training & - & 283.547 & 3.073 .027 & 3.356 .574 \\
\hline Technical support & 210.000 & 30.675 & 51.217 & 291.892 \\
\hline $\begin{array}{l}\text { Administrative } \\
\text { services }\end{array}$ & 420.000 & 61.749 & 256.086 & 737.835 \\
\hline Current maintenance & 210.000 & 21.911 & 1.024 .342 & 1.256 .253 \\
\hline Total & 840.000 & 1.194 .644 & 6.453 .356 & 8.488 .000 \\
\hline \hline
\end{tabular}

At the second level of allocation, activity costs are allocated to services as cost objects with the help of appropriate activity cost drivers. Activity cost drivers and their volume are shown in Table 5.

Table 5. Activity costs

\begin{tabular}{||l|c|c|c|c|c|c|c||}
\hline \multicolumn{1}{|c|}{ Activities } & $\begin{array}{c}\text { Activity cost } \\
\text { drivers }\end{array}$ & Pilates & Bodyshape & Zumba & Aerobics & Gym & Total \\
\hline $\begin{array}{l}\text { Individual } \\
\text { training }\end{array}$ & $\begin{array}{c}\text { Number of } \\
\text { participants }\end{array}$ & 5 & 4 & 3 & 6 & 32 & 50 \\
\hline $\begin{array}{l}\text { Group } \\
\text { training }\end{array}$ & $\begin{array}{c}\text { Number of } \\
\text { participants }\end{array}$ & 96 & 64 & 25 & 94 & 71 & 350 \\
\hline $\begin{array}{l}\text { Technical } \\
\text { support }\end{array}$ & $\begin{array}{c}\text { Number of } \\
\text { computer } \\
\text { maintenance cases }\end{array}$ & 12 & 12 & 12 & 12 & 12 & 60 \\
\hline $\begin{array}{l}\text { Administrativ } \\
\text { services }\end{array}$ & Number of users & 103 & 70 & 30 & 102 & 105 & 410 \\
\hline $\begin{array}{l}\text { Current } \\
\text { maintenance }\end{array}$ & Square meters & 90 & 90 & 90 & 90 & 30 & 390 \\
\hline \hline
\end{tabular}


Data given above shows that activity costs are allocated to individual services, cost objects, by applying the cost rate of each activity. The cost rate of each activity is a quotient of activity cost and activity cost driver. The cost rate for each activity is given in Table 6.

Table 6. Activity cost rate

\begin{tabular}{|l|c|c|c|}
\hline \multicolumn{1}{|c|}{ Activities } & Total costs & Activity cost driver & Cost rate \\
\hline Individual training & 2.845 .446 & 50 & 56.909 \\
\hline Group training & 3.356 .574 & 350 & 9.590 \\
\hline Technical support & 291.892 & 60 & 4.865 \\
\hline Administrative services & 737.835 & 410 & 1.800 \\
\hline Current maintenance & 1.256 .253 & 390 & 3.221 \\
\hline
\end{tabular}

We get total costs by multiplying the previously calculated cost rates of each activity and activity cost driver of each service - cost object. Table 7 shows the amount of activity costs allocated to cost objects.

Table 7. Allocating activity costs to cost objects

\begin{tabular}{|c|c|c|c|c|c|c|c|c|c|c|c|}
\hline \multirow[b]{2}{*}{ Activity } & \multirow[b]{2}{*}{ 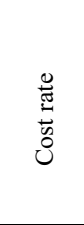 } & \multicolumn{2}{|c|}{ Pilates } & \multicolumn{2}{|c|}{ Body shape } & \multicolumn{2}{|c|}{ Zumba } & \multicolumn{2}{|c|}{ Aerobics } & \multicolumn{2}{|c|}{ Gym } \\
\hline & & 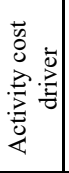 & $\frac{n}{0}$ & 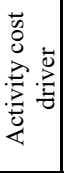 & 离 & 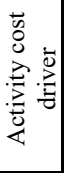 & 荀 & 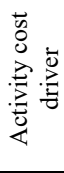 & 造 & 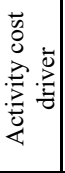 & 递 \\
\hline $\begin{array}{l}\text { Individual } \\
\text { training }\end{array}$ & 56.909 & 5 & 284.545 & 4 & 227.636 & 3 & 170.727 & 6 & 341.453 & 32 & 1.821 .085 \\
\hline $\begin{array}{l}\text { Group } \\
\text { training }\end{array}$ & 9.590 & 96 & 920.660 & 64 & 613.774 & 25 & 239.755 & 94 & 901.480 & 71 & 680.905 \\
\hline $\begin{array}{l}\text { Technical } \\
\text { support }\end{array}$ & 4.865 & 12 & 58.378 & 12 & 58.378 & 12 & 58.378 & 12 & 58.378 & 12 & 58.378 \\
\hline $\begin{array}{l}\text { Administra } \\
\text { tive } \\
\text { services }\end{array}$ & 1.800 & 103 & 185.358 & 70 & 125.972 & 30 & 53.988 & 102 & 183.559 & 105 & 188.958 \\
\hline $\begin{array}{l}\text { Current } \\
\text { maintenance }\end{array}$ & 3.221 & 90 & 289.905 & 90 & 289.905 & 90 & 289.905 & 90 & 289.905 & 30 & 96.635 \\
\hline Total & & & .738 .846 & & 1.315 .664 & & 812.753 & & 1.774 .775 & & 2.845 .961 \\
\hline
\end{tabular}

The total cost of each cost object is determined by adding together the overhead costs allocated to cost objects and coach salary costs, as shown in Table 8. 
Table 8 Overview of the total annual cost of the sports center

\begin{tabular}{||l|c|c|c|c|c|c||}
\hline Elements & Pilates & $\begin{array}{c}\text { Body } \\
\text { shape }\end{array}$ & Zumba & Aerobics & Gym & Total \\
\hline $\begin{array}{l}\text { Salary } \\
\text { costs }\end{array}$ & 600.000 & 1.200 .000 & 600.000 & 1.200 .000 & 2.400 .000 & 6.000 .000 \\
\hline $\begin{array}{l}\text { Overhead } \\
\text { costs }\end{array}$ & 1.738 .846 & 1.315 .664 & 812.753 & 1.774 .775 & 2.845 .961 & 8.488 .000 \\
\hline $\begin{array}{l}\text { Total } \\
\text { costs }\end{array}$ & 2.338 .846 & 2.515 .664 & 1.412 .753 & 2.974 .775 & 5.245 .961 & 14.488 .000 \\
\hline
\end{tabular}

\section{Performance measurement in sports organizations}

Organizations that successfully integrate a costing method adapted to the changing business environment and an appropriate performance measurement system are more likely to gain, maintain and enhance competitive advantage on a highly competitive global market. A well-designed and successfully implemented costing method in sports organizations, that provide a variety of services by performing specific activities using different resources, makes it possible to clearly identify the contribution and role of each activity in the achievement of defined tasks. In this sense, activity-based costing is an adequate basis for identifying activities performed in the organization, looking at how they are performed and identifying opportunities for their improvement. Activity-based costing information base is a good starting point for deploying modern performance measurement systems such as, among others, Balanced Scorecard (BSC), thus integrating performance measurement and management systems across the organization. The multiple links between activity-based costing and Balanced Scorecard are shown in Figure 1.

Balanced Scorecard is a performance measurement system that makes it possible to transform a business strategy into a comprehensive and efficient enterprise management system. Balanced Scorecard provides an overview of financial performance measures evaluating an organization's performance including operating costs, total revenue, profits etc, as well as non-financial performance measures that can signal that financial results are at risk and include customer satisfaction, customer retention, customer loyalty, the use of facilities, waiting times and the like (Beech, Chadwick 2004, p. 248). Improving the performance of one perspective can improve the performance of another one.

Given that managers need a comprehensive overview and balance between financial and operational performance, Balanced Scorecard offers four perspectives (Kaplan \& Norton, 2001):

- Financial perspective - How do we look to shareholders?

- Customer perspective - How do customers see us?

- Internal process perspective - What must we excel at? 
- Learning and growth perspective - Can we continue to improve and create value?

Figure 1. ABC to BSC relationship

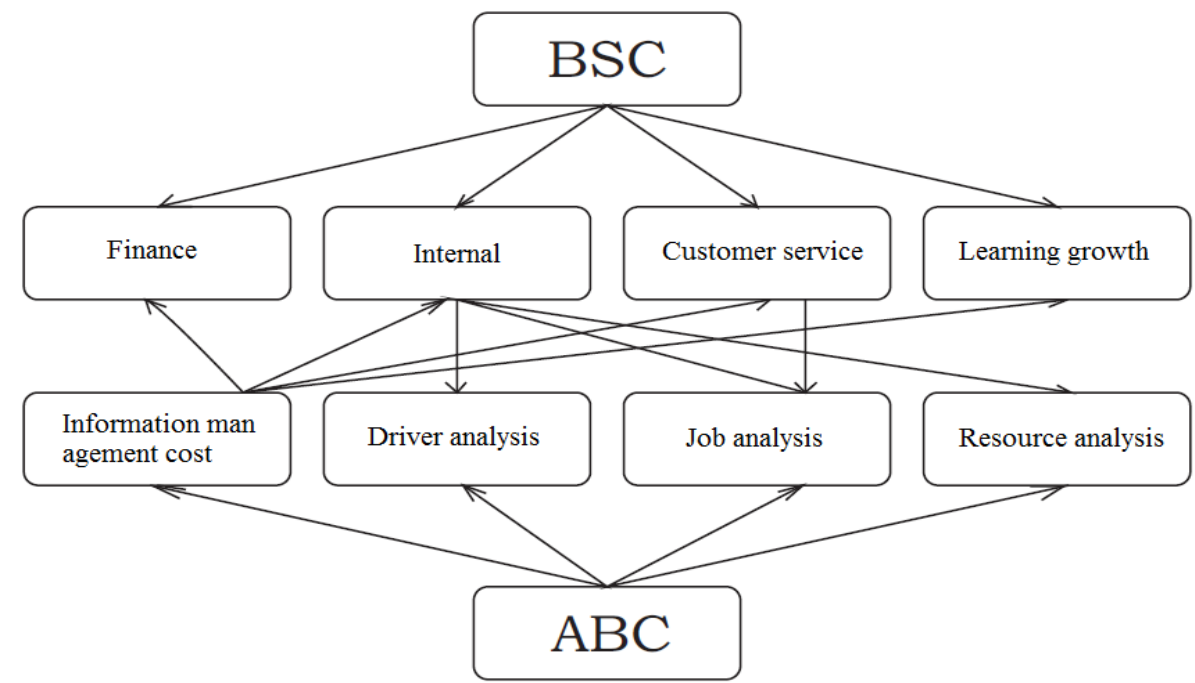

Source: ShuLiang, L., Jing, W. (2016) Analysis on the Combination of Activity-Based Costing and Balanced Scorecard. Advances in Social Science, Education and Humanities Research (ASSEHR), Vol. 65, p. 364.

Each organization should develop its own Balanced Scorecard with performance measures within each perspective, consistent with the strategy and goals defined. Balanced Scorecard is an essential tool for strategy implementation in companies where the strategy is clearly defined (Antić, Novićević Čečević 2018, p. 471-486). For businesses where the strategy is not clearly defined, Balanced Scorecard will serve as a mechanism for developing business unit strategy. The defined strategy is delegated to lower organizational levels with the help of a strategy map. A strategy map is visually an organizational strategy that outlines the goals of internal processes underlying value creation and organizational learning and growth that support internal processes. The goals in the strategy map are later translated into specific goals and measures in Balanced Scorecard. An example map for the Balanced Scorecard of the fitness center is shown in Figure 2.

Financial perspective measures performance through profit margins, start-up costs, salary costs etc. Profit margins are measured as follows (Stewart 2007, p. 119):

$$
\text { Profit margin }=((\text { Income }- \text { Expenses }) / \text { Revenue }) * 100
$$


Figure 2 Balanced Scorecard of the fitness center

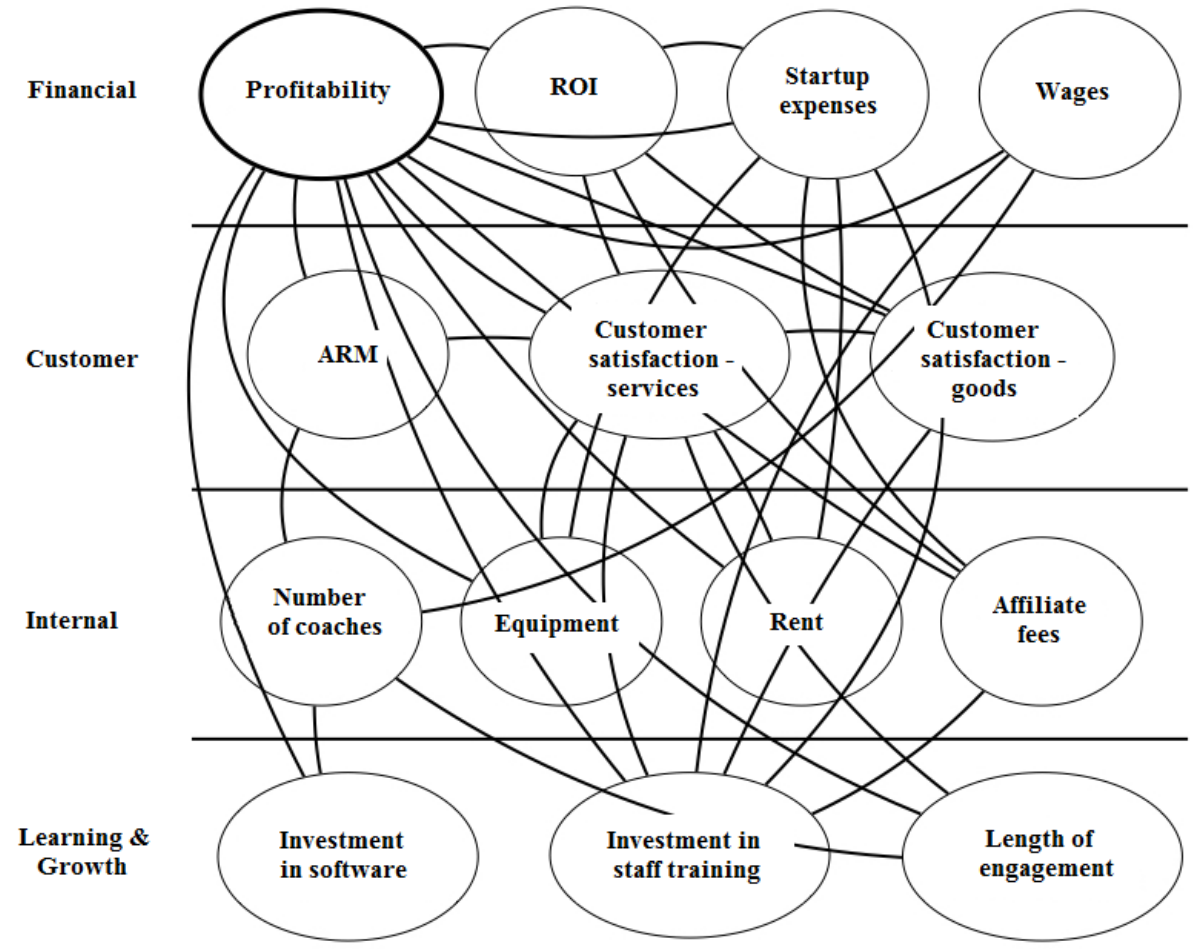

Source: Aronowitz, J. (2018) Optimize Your Fitness, Optimize Your Business: The Balanced Scorecard Analysis and Application for the CrossFit Affiliate. USA: Claremont McKenna College, p. 66.

An important indicator in the financial perspective is the start-up costs that include all the expenses necessary for a fitness center to start operating. This indicator is significant for sports entities that started their business in the current year. Within the financial perspective, it is important to determine the salary costs related to the coach and owner earnings.

Customer perspective measures customer satisfaction, the number of members, average revenue per member, average exercise time, average wait time, and positive feedback rise. Customer satisfaction is measured by the percentage change in membership between periods and the percentage change in revenue from services between periods. The number of members relates to indicators such as the cost of recruiting members, membership fees, as well as a coach/member ratio that shows how many members each coach is in charge of. The annual membership growth shows the number of new members the fitness center gets annually. Client Retention Rate (CRR) (www.fitnessbusinesspodcast.com) is the ratio between the 
number of clients on a given day at the beginning and the number of the same clients on a given day at the end of the business year. This indicator is very important because it indicates when the fitness center's profitability is threatened. The value of this indicator below $60 \%$ indicates that more clients are leaving than desired and that the fitness center must take urgent action to find out what is causing the clients to leave. The interview method, as well as benchmarking with immediate competitors can be used for this purpose. The reasons for clients to leave can be different, such as the departure of a popular coach, outdated exercise methods and programs etc. Average Revenue per Member (ARM) can be a measure of how much a sports entity is able to attract new members with its attractiveness and variety of services. It is calculated as follows (Stewart 2007, p. 122):

\section{Average revenue per member $=$ Gross revenue/number of members}

Within this perspective, one can also measure the average exercise time that represents the average time the visitor has spent exercising. Average waiting time indicates the average waiting time for a user to free up a specific exercise device (in minutes). Increasing positive feedback is achieved through user surveys.

The internal process perspective includes indicators relating to the number of coaches, equipment costs, rental costs and membership fees. Information on the number of coaches can be obtained by reviewing the payroll, while the ratio between the number of coaches and the number of members is measured via a coach/member ratio. Within this perspective, it is important to measure the number of employees who are certified and licensed to work. By this we mean the number of coaches, managers and administrative staff who have the required degree of education. The rental cost is determined by the amount of rent and the costs that arise from adjusting the premises and obtaining the necessary permits. In addition to these indicators, it is important to calculate the fitness center capacity. The area of the fitness center refers to the fitness center location in square meters and is necessary to adequately determine the fitness center's capacity. The capacity of the fitness center is measured by the number of people who can exercise at the fitness center at a time. In addition to this indicator, it is also important to determine revenue per square meter that measures how much revenue the space we use brings us (www.club-intel.com). This indicator can suggest whether the existing space is being used sufficiently and help evaluate what is being offered and in what form. Sometimes, simply moving the equipment in the same space can stimulate customer activity and their number. It is not good if clients leave - it is the ambience they don't like, it is not because a competitor has appeared nearby. Equipment costs are incurred based on procurement costs and maintenance costs of the equipment. Investing in equipment represents all the funds invested in the purchase of training equipment and devices. It is also important to have an insight into the annual growth of investment. In addition to these indicators, membership fees and insurance costs are important indicators within the internal process perspective. 
Within the learning and growth perspective, investment in employee training, in management software, engagement period, the length of continued membership, and the number of additional benefits are analyzed. Investing in employee training refers to the resources spent on training the coaches and the managers. Investment in software for management purposes refers to the funds invested in the procurement of software that should contribute to greater efficiency. The engagement period is measured by the ratio between the total number of monthly memberships for all members and the number of current members. In addition to this indicator, it is important to determine the length of continued membership for all members. A special indicator is the number of additional benefits, which is measured by the number of additional amenities offered by the fitness center, such as the number of parking spaces, the number of computers on which users can record their exercise progress and the like.

Table 9. Fitness center goals, measures, targets and initiatives

\begin{tabular}{|c|c|c|c|c|}
\hline Perspectives & Goals & $\begin{array}{c}\text { Measures to be } \\
\text { taken }\end{array}$ & Targets & Initiatives \\
\hline $\begin{array}{c}\text { Financial } \\
\text { perspective }\end{array}$ & $\begin{array}{c}\text { Increase } \\
\text { market } \\
\text { share by a } \\
\text { percentage } \\
\text { in a specific } \\
\text { period }\end{array}$ & $\begin{array}{l}\text { Advertising } \\
\text { recommendations }\end{array}$ & $\begin{array}{l}\text { Individuals } \\
\text { or groups } \\
\text { ready to be } \\
\text { healthy and } \\
\text { in top form }\end{array}$ & Discounts \\
\hline $\begin{array}{c}\text { Customer/client } \\
\text { perspective }\end{array}$ & $\begin{array}{l}\text { Customer } \\
\text { satisfaction }\end{array}$ & $\begin{array}{c}\text { Specific } \\
\text { individual } \\
\text { training regimes }\end{array}$ & $\begin{array}{c}\text { Returning } \\
\text { clients }\end{array}$ & Recommendations \\
\hline $\begin{array}{l}\text { Internal process } \\
\text { perspective }\end{array}$ & $\begin{array}{l}\text { Teamwork } \\
\text { that will } \\
\text { contribute } \\
\text { to client } \\
\text { returns }\end{array}$ & $\begin{array}{l}\text { Coaches and } \\
\text { instructors work } \\
\text { together. } \\
\text { Continuous } \\
\text { updating of } \\
\text { exercises and } \\
\text { maintenance of } \\
\text { exercise } \\
\text { equipment }\end{array}$ & $\begin{array}{l}\text { Existing } \\
\text { and new } \\
\text { clients }\end{array}$ & \\
\hline $\begin{array}{l}\text { Learning and } \\
\text { growth } \\
\text { perspective }\end{array}$ & $\begin{array}{c}\text { New } \\
\text { exercise } \\
\text { techniques } \\
\text { and keeping } \\
\text { up with } \\
\text { trends }\end{array}$ & $\begin{array}{c}\text { Renewing coach } \\
\text { licenses and } \\
\text { certifications }\end{array}$ & $\begin{array}{c}\text { All } \\
\text { employees }\end{array}$ & All employees \\
\hline
\end{tabular}

Adapted from: https://www.coursehero.com/file/p24jmh/BALANCED-SCORECARDOconee-Fitness-Center-Objectives-Measures-Targets/ (23.05.2019). 
The aforementioned performance measures within each perspective are not universal. They can be supplemented and modified depending on the nature, resources, activities, mission and goals of the sports entity. Financial and nonfinancial performance measurement is of particular importance for identifying potential operational problems and proposing measures and activities that need to be taken to make changes to the process organization and how the service is delivered, the final service etc. The proposed goals, measures and initiatives for the fitness center are given in Table 9.

In addition to management with adequate knowledge and skills, organizational structure and decision-making systems, a modern fitness center can successfully operate if it ensures customer satisfaction by hiring highly educated and professional coaches, directly involved in the provision of services, as well as other qualified personnel in accordance with the needs of defined jobs. People are known to visit fitness centers to maintain good physical fitness and preserve their health. For a fitness center to operate successfully, it is necessary to recognize what sports amenities its visitors prefer and to create an assortment of their offer according to their needs. This can be achieved if the hygiene of the facility is at an enviable level, with pleasant time spent there, a pleasant atmosphere with appropriate music and lighting, functional equipment and high-quality and safe materials, friendly employees, always available, open to cooperation, efficient and competent (Dugalic 2007, p. 126). The control of work is achieved by comparing the results of work with those previously planned, paying attention to market trends, as well as to competition actions.

\section{Conclusion}

The activity-based costing process begins with an analysis of the activities performed in the organization from the perspective of available and accessible resources. Allocation of resource costs to activities is made on the basis of how much resources are required to perform the activity. The costs are then allocated from activities to cost objects by activity cost drivers. Activity cost drivers measure the number of individual activities performed to produce a product. This costing method very quickly captured the attention of managers of manufacturing organizations, and because of its information basis suitability, has been successfully applied in service organizations. An example of service organizations that successfully apply the original or enhanced activity-based costing is sports organizations. The variety of services they provide, the simplicity of the activities to provide, and the low consumption of resources are just some of the reasons for the successful implementation of activity-based costing in sports organizations.

In addition to applying costing methods adapted to the changing business environment, managers of sports organizations are also interested in changing how they measure performance. Measuring the performance of sports organizations is 
crucial, especially for those that are non-profit-making and aim to accomplish a core mission. Balanced Scorecard is a system for measuring the performance of an organization through four perspectives: financial, learning and growth perspective, internal process perspective and customer/client perspective. It has been successfully implemented in sports organizations.

Through the implementation of activity-based costing and Balanced Scorecard, sports organizations are able to:

- More accurately identify product costs and significant financial and nonfinancial measures that help manage costs;

- Better measure profitability and make strategic decisions on prices, product lines and market segments based on a more complete information base;

- Exactly allocate overheads and identify areas where losses occur;

- Determine cause and effect relationships between expenses and resource consumption;

- Carry out targeted cost reductions and efficiency gains through budget management and control;

- Increase productivity and identify non-value-added activities; and

- Provide a basis for strategic decision making and measurement of continuous improvement and performance.

The financial perspective makes it easier to identify the strategic resource needs, for which the monies are budgeted for annually, and the cost information provided by $\mathrm{ABC}$ allows one to monitor whether and how much resource use is deviating from the expected. Due to the information on resource costs, quality, cost drivers, time required to do the job, and the innovation that $\mathrm{ABC}$ brings, it is possible to lay a good foundation for managing the perspective of internal business processes within the BSC, as well as the learning and growth perspective. Also, due to the analysis and more reliable measurement of marketing, general administration and administration costs, technical support costs and the like, which $\mathrm{ABC}$ provides, it is easier to manage the customer perspective within BSC and monitor the profitability of service users. Analyzing the aforementioned advantages from the application of $\mathrm{ABC}$ and $\mathrm{BSC}$, as systems that enable adequate business decision-making, it can be concluded that their application would be useful for successful management and preservation of competitive advantages, not only of sports organizations, but also of other manufacturing and service companies. 


\section{References}

Antić, Lj., \& Sekilić, V. (2016) Activity Based Costing in Helath Care Organizations. Facta Universitatis Series: Economics and Organization Vol. 13, No 4, 357-363.

Antić, Lj., Novićević Čečević, B. (2016) Obračun troškova zasnovan na aktivnostima u funkciji unapređenja kvaliteta visokoškolskih institucija. Konkurentnost $i$ održivost razvoja privrede Republike Srbije: 586 . Niš: Ekonomski fakultet.

Antić, Lj., Novićević Čečević, B. (2018) Primena Balanced Scorecard-a u visokoškolskih institucijama. Konkurentnost i održivi razvoj privrede Republike Srbije: 471-486. Niš: Ekonomski fakultet.

Aronowitz, J. (2018) Optimize Your Fitness, Optimize Your Business: The Balanced Scorecard Analysis and Application for the CrossFit Affiliate. USA: Claremont McKenna College.

Beech, J., Chadwick, S. (2004) The Business of Sport Management. UK: Prentice Hall.

Boussabaine, A. H., Kirkham, R. J., Grew, R. J. (1999) Modelling total energy costs of sport centres. Facilities, Vol. 17., Issue: 12/13: 452-461.

Ćosić, M. (2012) Specifičnosti menadžmenta u industriji sporta. Proceedings of the International Scientific Conference Management 2012: 131-137. Mladenovac: Fakultet za poslovno industrijski menadžment.

Dimitropoulos, P. (2007) Activity - Based Costing in Sport Organizations: Theoretical Background \& Future Prospects. Sport Management International Journal, Vol. 3., No. 2: $17-25$.

Drury, C. (2008) Management and cost accounting. UK: Cengage Learning.

Dugalić, S. (2007) Menadžment sportskih objekata. Beograd: Viša škola za sportske trenere.

Estrin, T., L., Kantor, J., Albers, D. (1994) Is ABC Suitable for Your Company?. Management Accounting, Vol: 75. Issue: 10.: 40-45.

Fitness Studio Operating \& Financial Benchmarking Report 2015, https://www.clubintel.com/wp-content/uploads/2015-Fitness-Studio-Operating-Financial-BenchmarkingReport-Abbreviated-Version.pdf (26.05.2019).

Fitness Studio Operating \& Financial Benchmarking Report 2018, https://fitnessbusinesspodcast.com/wp-content/uploads/2018/11/2018-AbbreviatedReport.pdf (26.05.2019).

Gómez, S., Opazo, M., Martí, C. (2007) Structural characteristics of sport organizations: Main trends in the academic discussion. Spain: IESE Business School - University of Navarra.

https://www.coursehero.com/file/p24jmh/BALANCED-SCORECARD-Oconee-FitnessCenter-Objectives-Measures-Targets/ (23.05.2019).

Kaplan, R., Norton, P. (2001) The Strategy Focused Organization, Boston MA: Harvard Business School Publishing Corp.

Kosmas, I., Dimitropoulos, P. (2014) Activity Based Costing in Public Sport Organizations: Evidence from Greece. Research Journal of Business Management, Vol: 8. Issue: 2.: 130-138.

Langston, C., Lauge-Kristensen, R. (2011) Strategic Management of Built Facilities. New York: Routledge.

Lussier, R., Kimball, D. (2014) Applied Sport Management Skills. USA: Human Kinetics.

Manev, G., Jakimovski, J. (2017) Role of knowledge management in sport organizations. Skola biznisa, No. 2.: 150-171. 
Milić, Z. (2009) Osnove menadžmenta neprofitnih organizacija. Beograd: Visoka strukovna škola za preduzetništvo.

ShuLiang, L., Jing, W. (2016) Analysis on the Combination of Activity-Based Costing and Balanced Scorecard, Advances in Social Science, Education and Humanities Research (ASSEHR), Vol: 65.: 363-366.

Slack, T. (1997) Understanding sport organizations: The application of organization theory. USA: Human Kinetics.

Stewart, B. (2007) Sport Funding and Finance. Netherlands: Elsevier.

Weygandt, J, Kimmel, P., Kieso D. (2008) Managerila Accounting. New Jersey: John Wiley \& Sons.

Zakon o sportu Republike Srbije, Član 3, tačka 6. i tačka 15., 04.02.2016. godine, https://www.mos.gov.rs/public/ck/uploads/files/Dokumenta/Sport/zakon-osportu/Zakon\%20o\%20sportu\%202016_.pdf(17.05.2019).

\section{OBRAČUN TROŠKOVA I MERENJE PERFORMANSI U FUNKCIJI UNAPREĐENJA KONKURENTNOSTI SPORTSKIH ORGANIZACIJA}

Apstrakt: Dinamično poslovno okruženje, porast učešća opštih troškova u strukturi ukupnih troškova, pooštrena konkurencija na globalnom tržištu i brojni drugi izazovi sa kojima se organizacije suočavaju, nametnule su potrebu za preispitivanjem postojećih metoda, osmišljavanjem novih metoda obračuna troškova i primenu adekvatnijih upravljačkih alata kako bi se unapredila informaciona podrška za obavljanje aktivnosti menadžmenta i kako bi se očuvala i unapredila konkurentska prednost. Pored tradicionalnih metoda obračuna troškova, organizacije primenjuju metode obračuna troškova primerene izmenjenom poslovnom okruženju, kao što je, između ostalih, obračun troškova po aktivnostima (Activity Based Costing - ABC). Pozitivna iskustva proizvodnih organizacija koje obračunavaju troškove po aktivnostima, doprinela su širenju primene obračuna troškova po aktivnostima na uslužne organizacije. Promene u načinu obračunavanja troškova usklađene su sa promenama $\mathrm{u}$ sistemima za merenje performansi, a sve $\mathrm{u}$ funkciji boljeg funkcionisanja organizacija i uspešnom odgovoru na zahteve izmenjenog poslovnog okruženja. U radu se analizira mogućnost primene obračuna troškova po aktivnostima i Balanced Scorecard-a (BSC-a) u sportskim organizacijama koje pružaju veliki broj specifičnih usluga.

Ključne reči: obračun troškova, aktivnosti, troškovi, sportske organizacije, Balanced Scorecard

\section{Acknowledgement}

The paper is the result of research based on obligations under the Agreement on the implementation and financing of research and development in 2020 (record number 451-03-68 / 2020-14 / 200100), concluded between the Ministry of Education, Science and Technological Development of the Republic of Serbia and the University of Niš, Faculty of Economics. 


\section{Authors' biographies}

Bojana Novićević Čečević, PhD, Assistant Professor, was born in 1983 in Niš. She graduated from the Faculty of Economics in Nis and successfully defended her master's thesis in the subject of Strategic Management Accounting. She defended her doctoral dissertation entitled Management and Accounting Support to Company Management in a Lean Business Environment in 2016 at the Faculty of Economics in Nis. Since October 2008, she has been working at the Faculty of Economics in Nis. She is the author of a large number of papers published in leading national journals and proceedings of scientific conferences, co-author of the monograph and workbook from Management Accounting and Cost Accounting.

Ljilja Antić, PhD, Full Professor, was born in 1968. She defended her doctoral dissertation entitled Calculation of costs by activities in the function of managing a modern company in 2003 at the Faculty of Economics in Nis, where she began her academic career in 1991 as an assistant trainee. Her interests include the field of accounting, with a special emphasis on management accounting and modern methods and concepts of calculation and cost management. She is the author of several monographs and numerous papers published in leading national journals and proceedings of scientific conferences.

Kristina Spasić was born in 1988 in Leskovac. She completed her studies at the Faculty of Economics, University of Nis in 2011 and graduated at the master of academic studies at the same faculty in 2013. The same year, she enrolled in doctoral academic studies, module Accounting. She is the winner of the award given by the Association of Accountants and Auditors of Serbia for the best students in the field of Accounting in 2012. Since 2014, she has been employed at the Business School of Vocational Studies in Leskovac, first as a teaching associate, then as a volunteer, and then as a teaching assistant. Since 2020 , she has been employed in the company for trade and services "Infodata group" d.o.o. Leskovac. She is the author and co-author of 32 papers published in scientific journals and thematic proceedings. 